\title{
ПОШИРЕНІСТЬ ГАСТРОЕЗОФАГЕАЛЬНОЇ РЕФЛЮКСНОЇ ХВОРОБИ ЗА ДАНИМИ ЕНДОСКОПІЧНИХ ДОСЛІДЖЕНЬ
}

\section{А. Бичков, М. М. Яхницька \\ Львівський національний медичний університет імені Данила Галицького}

PЕЗЮМЕ. Гастроезофагеальна рефлюксна хвороба (ГЕРХ) залишається на сьогодні однією з найактуальніших проблем гастроентерології. Значна поширеність даної патології серед осіб працездатного віку погіршує соціально-економічні умови їх життя та потребує подальших досліджень для ранньої діагностики та лікування. Різноманітність клінічних проявів, не до кінця з'ясовані етіопатогенетичні ланки зумовлюють постійний інтерес до вивчення ГЕРХ. На жаль, достовірні дані щодо поширеності ГЕРХ в Україні практично відсутні.

Мета - дослідити поширеність ендоскопічно позитивної форми ГЕРХ серед пацієнтів Новояворівської районної лікарні протягом 2011-2015 років.

Матеріали та методи. Ретроспективно проаналізовано журнали реєстрації ендоскопічних досліджень з 2011 по 2015 рік. Ендоскопічні дослідження проводили фіброгастроскопами фірм Olympus та Pentax. Зміни слизової оболонки стравоходу визначали за Лос-Анджелеською системою класифікації (1997). Комп'ютерну обробку даних проводили за допомогою програми Microsoft Excel.

Результати. За період 2011-2015рр. виконано 7571 ендоскопію, у 959 обстежених (12,7 \%) діагностовано ерозивний езофагіт. У 2011 р. виявлений 241 пацієнт з ерозивними змінами стравоходу: ст. А - 230 хворих, ст. В 10 осіб та ст. D - 1 хворий. За 2012 рік діагностовано 117 випадків езофагіту: 110 - ст. A, 6 - ст. В, 1 - ст. С. Впродовж 2013 року було встановлено 239 випадків езофагіту: 197 - ст. А, 34 - Ст. В, 5 - Ст. С та 3 - Ст. D. Структура ендоскопічно позитивної ГЕРХ у 2014 році була наступною: 94 випадків езофагіту ст. А, 20 випадків езофагіту ст. В і 3 випадки езофагіту ст. С. У 2015 році виявлено 245 пацієнтів з ерозивним езофагітом, з них 201 - з езофагітом ст. А, 41 - 3 езофагітом ст. В та 3 - з езофагітом ст. С.

Висновки. Поширеність ендоскопічно позитивної форми ГЕРХ у 2011-2015 роках на території обслуговування Новояворівської РЛ № 1 становила в середньому 13,4%. Найхарактернішим для ерозивних уражень стравоходу був езофагіт ст. А. Найчастіше ерозивні езофагіти виявляли у пацієнтів працездатного віку.

КЛючОВІ СлОВА: гастроезофагеальна рефлюксна хвороба; ерозивний езофагіт; поширеність.

Вступ. Гастроезофагеальна рефлюксна хвороба (ГЕРХ) як самостійна нозологічна одиниця була класифікована ще в жовтні 1997 року на міждисциплінарному конгресі гастроентерологів і ендоскопістів в м. Генвалі (Бельгія). Значна поширеність даної патології, різноманітність клінічних проявів, труднощі діагностики і лікування зумовили те, що Всесвітня організація охорони здоров'я визнала ГЕРХ захворюванням XXI століття [1].

Згідно з епідеміологічними даними, поширеність ГЕРХ у країнах Західної Європи та Північної Америки становить 30-40 \% дорослого населення, з них 10 \% відчувають печію щоденно, проте тільки 2 \% пацієнтів отримують лікування з приводу ГЕРХ. Аналіз даних літератури показав, що 69,7 \% міських жителів Російської Федерації страждають на печію, з них 22,7 \% опитаних відчувають печію більше 2-3 разів на тиждень. У Японії, де ендоскопічне обстеження верхніх відділів шлункового каналу $\epsilon$ скринінговим, частота виявлення езофагітів становить 16,5 \% від всіх обстежених осіб [5]. За іншими даними, в останні роки частота виявлення ерозивної форми ГЕРХ зросла з 3,1 до 16,0 \%. Захворюваність на рефлюкс-езофагіт (РЕ) зростає з віком, причому його ускладнення виявляють, як правило, у хворих старше 50 років [7]. Захво- рюваність на ГЕРХ у світі складає 5 випадків на 1000 населення на рік [2].

В Україні статистична реєстрація ГЕРХ почалася з 2009 року, i, на жаль, дані ще не $є$ повними, захворюваність складає 10 випадків на 1000 населення [3]. Наявні повідомлення, що поширеність ГЕРХ в Україні складає від 11,1 \% до 30 \% [6]. За іншими даними, реальна поширеність ГЕРХ може бути значно більшою, оскільки близько 25 \% хворих на ГЕРХ не звертаються до лікарів, займаються самолікуванням, у частини пацієнтів ГЕРХ має безсимптомний перебіг [7].

ГЕРХ - це хронічне захворювання з довготривалим, часто рецидивуючим перебігом, що значно погіршує якість життя хворого. Проте значення цієї патології недооцінюють як пацієнти, так і лікарі. Значна частина пацієнтів лікуються самостійно. В Україні діагноз ГЕРХ переважно встановлюють лише за наявності ендоскопічних змін у стравоході. Реальна поширеність захворювання вивчена мало. Це пов'язано з наявністю атипових та типових клінічних проявів: від періодичної печії до тяжких ускладнень рефлюкс-езофагіту, що зумовлюють необхідність госпіталізації (близько 5 \% пацієнтів) [5].

Захворюваність на ГЕРХ можна порівняти 3 айсбергом, підводну частину якого складають пацієнти з періодичною печією, що не викликає за- 
Огляди літератури, оригінальні дослідження, погляд на проблему

непокоєння і не $\epsilon$ причиною звернення за медичною допомогою (70-80 \% випадків); середня надводна частина - це хворі 3 неускладненим рефлюкс-езофагітом, які лікуються в амбулаторних умовах (25\%). Пацієнти з ускладненнями (кровотечі, стриктури стравоходу, стравохід Барретта), які потребують госпіталізації, відповідно, порівнюються із верхівкою айсберга $(5 \%)[5,8]$.

Тому на сьогодні $\epsilon$ актуальним аналіз кількості виявлених ерозивно-виразкових змін слизової оболонки стравоходу для моніторингу поширеності ГЕРХ.

Мета - вивчити поширеність ендоскопічно позитивної форми ГЕРХ серед пацієнтів Новояворівської районної лікарні № 1 протягом 2011-2015 років.

Матеріал і методи дослідження. Ретроспективно проаналізовано журнали реєстрації ендоскопічних досліджень з 2011 по 2015 рік, загалом 7571 обстеження.

Обстеження проводили фіброгастроскопами фірм Olympus та Pentax.

Зміни слизової оболонки стравоходу визначали за Лос-Анджелеською системою класифікації (1997) [4], а саме: ступінь А - один або більше дефектів слизової оболонки, обмежених складками слизової, довжина яких не перевищує 5 мм; ступінь В - один або більше дефектів слизової оболонки, обмежених складками слизової, довжина яких перевищує 5 мм; ступінь С - один або більше дефектів слизової оболонки, розміщених на складках і між ними (можуть зливатися між собою), але ураження займає менш ніж 75 \% периметра стравоходу; ступінь D - пошкодження сли- зової оболонки займає більш ніж 75 \% периметра стравоходу. Мінімальні зміни слизової оболонки стравоходу (еритема, набряк) не враховували.

Комп'ютерну обробку даних проводили за допомогою програми Microsoft Excel.

Результати й обговорення. Новояворівська РЛ № 1 обслуговує 34139 осіб дорослого населення. За період 2011-2015 рр. виконано 7571 ендоскопію. У 959 (12,7 \%) осіб діагностували ерозивний езофагіт різного ступеня тяжкості (рис. 1).

Як видно з рисунка 1, кількість діагностованих ерозивних езофагітів (23,9 \%) була найбільшою у 2011 році, найменшою - у 2012 та 2014 роках (7,6 \% та $8 \%$ відповідно).

Загальна захворюваність на ерозивну форму ГEPX у 2011-2015 роках виглядала наступним чином (рис. 2)

Як видно з рисунка 2, загальна захворюваність на ерозивний варіант ГЕРХ має хвилеподібний перебіг.

Проводячи аналіз журналу реєстрації ендоскопічних досліджень за 2011 рік ми з'ясували (табл. 1), що у 3,7 \% осіб було діагностовано езофагіт стадії В (середній вік пацієнтів- $(57,5 \pm 5,8)$ років). У 0,4 \% хворих виявлено езофагіт стадії D; у 233 пацієнтів встановлено ерозивний езофагіт стадії А. 3 них - у 20,8 \% випадків діагностовано виключно ураження слизової оболонки стравоходу (середній вік хворих $(37,6 \pm 2,2)$ років). У $3,7 \%$ пацієнтів із езофагітом стадії А виявлено одночасно зміни шлунка та дванадцятипалої кишки у вигляді ерозивного гастриту / бульбіту (середній вік хворих $(38 \pm 2,2)$ років). У 17,8 \% хворих (середній вік $(36,3 \pm 1,64)$ років) виявлено поєднання езофа-

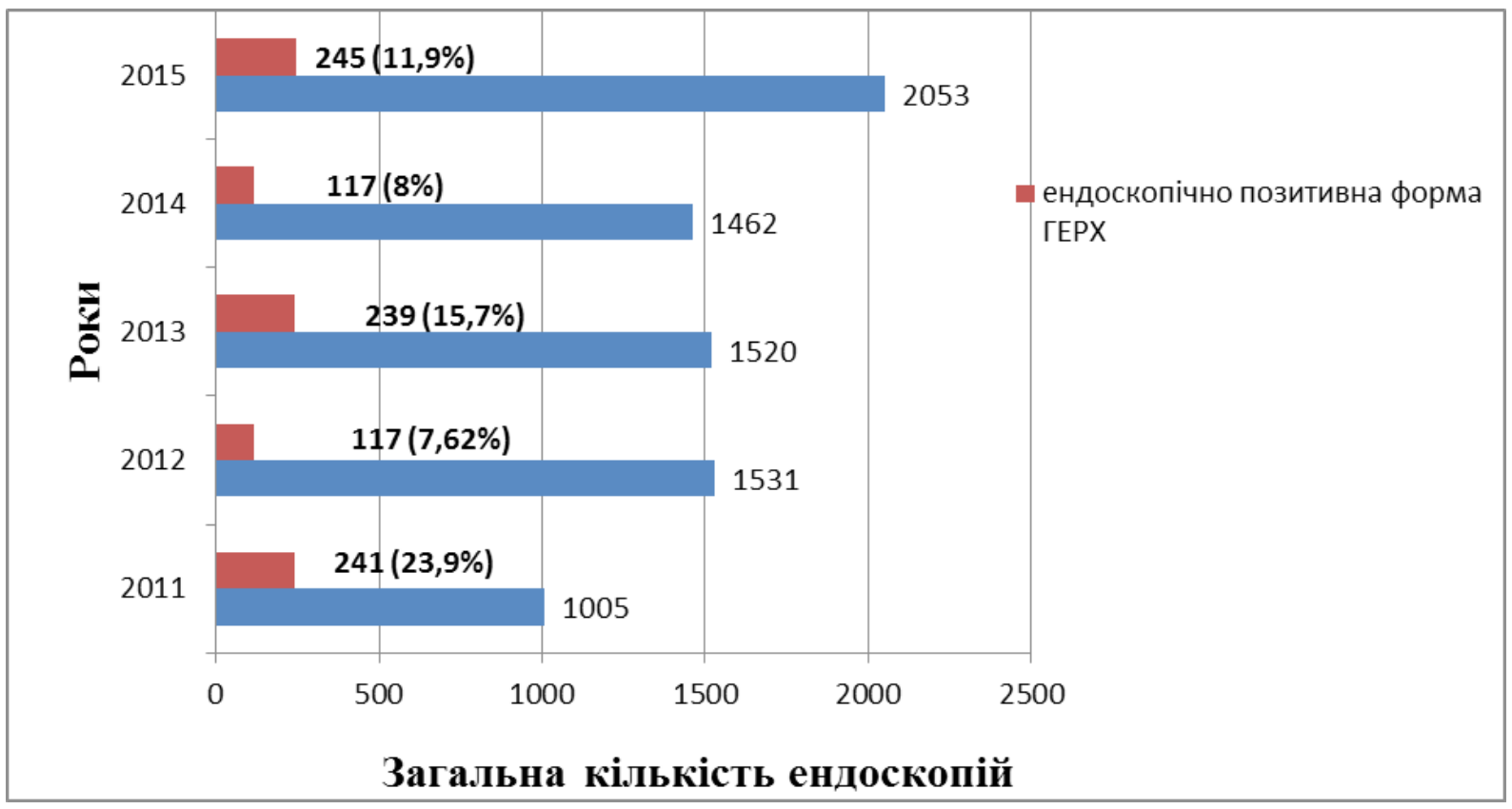

Рис. 1. Поширеність ерозивного езофагіту за даними ендоскопічних досліджень. 
Огляди літератури, оригінальні дослідження, погляд на проблему

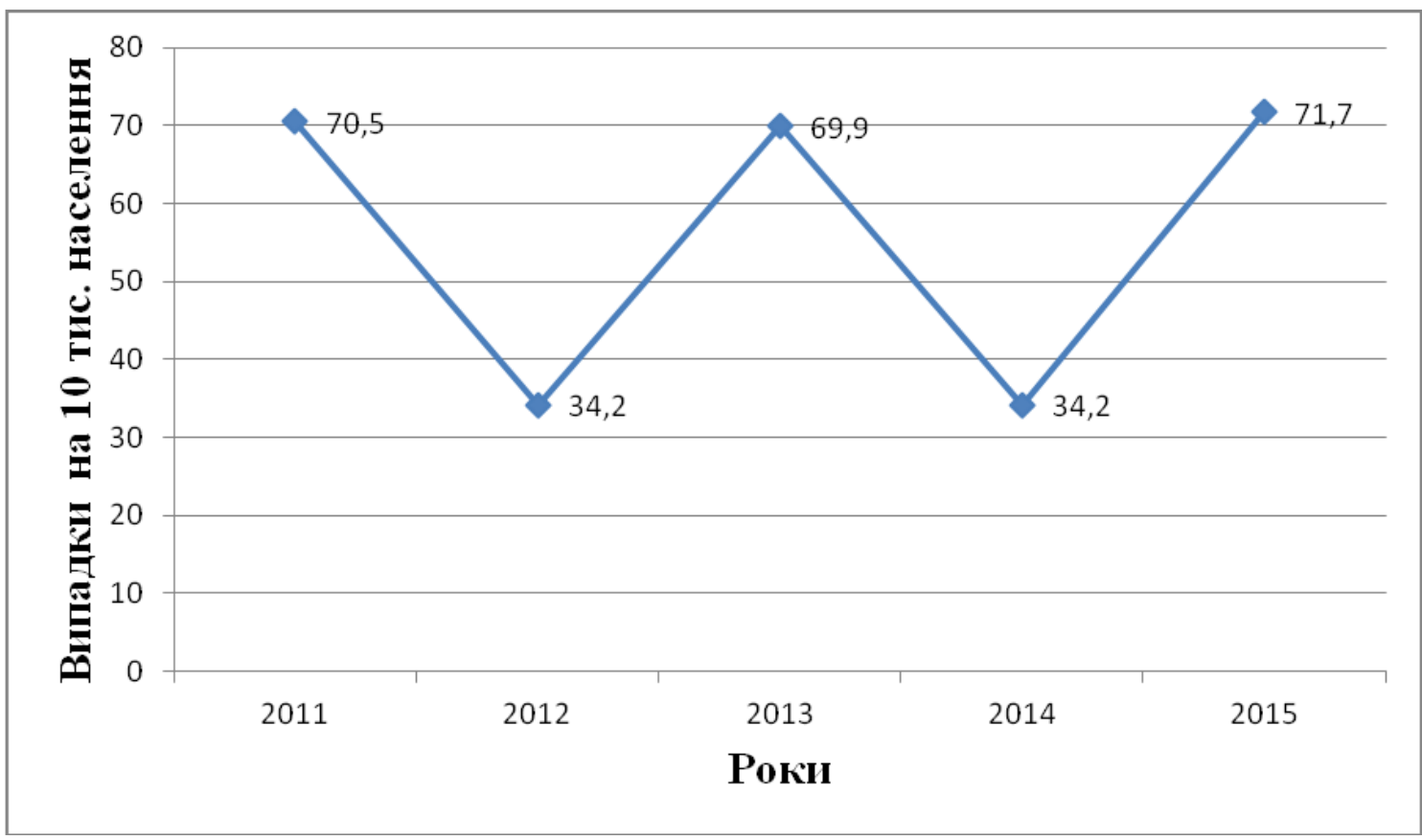

Рис. 2. Загальна захворюваність на ендоскопічно позитивну форму ГЕРХ на території обслуговування Новояворівської РЛ № 1 (на 10 тис. населення).

Таблиця 1. Поєднання езофагіту стадії А з іншими захворюваннями шлунково-кишкового каналу

\begin{tabular}{|c|c|c|c|c|c|}
\hline Рік & $\begin{array}{c}\text { Ізольоване } \\
\text { ураження } \\
\text { стравоходу } n(\%)\end{array}$ & $\begin{array}{c}\text { Патологія } \\
\text { шлунка } \\
n(\%)\end{array}$ & $\begin{array}{c}\text { Патологія } \\
\text { дванадцятипалої } \\
\text { кишки } \mathrm{n}(\%)\end{array}$ & $\begin{array}{c}\text { дгр } \\
\text { (\%) }\end{array}$ & $\begin{array}{c}\text { Діафрагмальна } \\
\text { грижа } \mathrm{n}(\%)\end{array}$ \\
\hline $\begin{array}{c}2011 \\
(n=241)\end{array}$ & $49(20,8)$ & $85(33,2)$ & $24(9,9)$ & $43(17,8)$ & $10(4,1)$ \\
\hline $\begin{array}{c}2012 \\
(n=117)\end{array}$ & $32(27,4)$ & $29(24,8)$ & $23(19,7)$ & $12(10,3)$ & $17(7,1)$ \\
\hline $\begin{array}{c}2013 \\
(n=239)\end{array}$ & $57(23,8)$ & $54(22,6)$ & $34(14,2)$ & $12(10,3)$ & $10(8,5)$ \\
\hline $\begin{array}{c}2014 \\
(n=117)\end{array}$ & $19(16,2)$ & $40(34,1)$ & $9(7,6)$ & $20(8,2)$ & $5(2,04)$ \\
\hline $\begin{array}{c}2015 \\
(n=245)\end{array}$ & $53(21,6)$ & $89(36,3)$ & $29(11,8)$ & \\
\hline
\end{tabular}

гіту стадії А із дуоденогастральним рефлюксом (ДГР). У 9,9 \% обстежених, окрім езофагіту, були зміни дванадцятипалої кишки (ерозивний бульбіт та виразка цибулини дванадцятипалої кишки). Морфологічні зміни слизової оболонки шлунка у пацієнтів з езофагітом стадії А спостерігали у 85 випадках. Мали місце також поодинокі випадки поліпів кардії та стравоходу. Грижу стравохідного отвору діафрагми діагностовано у 10 пацієнтів, що становило 4,1 \% усіх пацієнтів з ендоскопічно позитивною формою ГЕРХ.

У 2012 році езофагіт стадії В виявлено у 6 пацієнтів (середній вік $(51,5 \pm 7,1)$ років), з них лише у 2 випадках були відсутні ураження шлунка та дванадцятипалої кишки. У хворого з езофагітом стадії С було діагностовано ерозивний гастрит. 110 хворих (середній вік $(41,53 \pm 1,28)$ років) мали езофагіт стадії А (середній вік $(41,5 \pm 1,28)$ років). Ізольоване ураження стравоходу з ерозіями не більше 5 мм було у 27,4 \% пацієнтів (середній вік $(38,7 \pm 2,06)$ років). Поєднання езофагіту стадії $\mathrm{A}$ із змінами слизової оболонки шлунка та дванадцятипалої кишки було у 24,8 \% та у 19,7 \% хворих відповідно. 10,3 \% обстежених, окрім езофагіту ст. А, мали ендоскопічні ознаки ДГР.

У 2013 році виявлено 14,2 \% пацієнтів з езофагітом стадії В (середній вік $(47,4 \pm 2,84)$ років): 3 них 20,6 \%-у поєднанні з патологією дванадцятипалої кишки (ерозивний бульбіт, виразка цибулини дванадцятипалої кишки), 29,4 \% - з гастропатіями (геморагічними, поверхневими). У 2,1 \% обстежених (віком $(64,0 \pm 7,7)$ років) діагностовано 
Огляди літератури, оригінальні дослідження, погляд на проблему

езофагіт стадії С. У 1,25 \% досліджених осіб віком $(75,0 \pm 5,56)$ років були наявні ознаки, характерні для езофагіту стадії D. У решти пацієнтів діагностовано езофагіт стадії А (середній вік $(43,08 \pm 1,13)$ років): у 23,8 \% встановлено ізольований езофагіт, у 14,2\% - поєднаний з патологією дванадцятипалої кишки, у 9,6 \% - з дуоденогастральним рефлюксом. У 7,1 \% осіб виявлена грижа стравохідного отвору діафрагми, а в 22,6 \% хворих були наявні зміни у шлунку.

Вивчаючи дані за 2014 рік ми встановили у 80,3 \% обстежених езофагіт стадії А (середній вік $(44,18 \pm 1,58)$ років), з них лише $16,2 \%$ пацієнтів мали ізольоване ураження стравоходу. 3 езофагітом стадії В було 17,1 \% хворих віком $(49,2 \pm 3,2)$ років. У $2,6 \%$ випадків виявлено езофагіт стадії С (середній вік хворих становив $(36,0 \pm 3,05)$ років).

У 2015 році було виявлено 245 пацієнтів з ендоскопічно позитивною формою ГЕРХ, у 81,6 \% 3 них діагностовано езофагіт стадії А (середній вік $(43,64 \pm 1,03)$ років). Аналізуючи структуру поєднаного ураження стравоходу та верхніх відділів шлунково-кишкового каналу ми встановили, що зміни у шлунку траплялися у 2,7 раза частіше, ніж зміни у дванадцятипалій кишці. Езофагіт стадії В спостерігали у 16,7 \% хворих віком $(47,14 \pm 2,29)$ років. У 1,7 \% пацієнтів ендоскопічна картина була характерною для езофагіту стадії С (середній вік $(66,6 \pm 3,33)$ років).

\section{ЛІТЕРАТУРА}

1. Бабак О. Я. Гастроэзофагеальная рефлюксная болезнь. От теории к практике / О. Я. Бабак // Сучасна гастроентерологія. - 2014. - № 4. - С. 38-44.

2. Бичков М. А. Гастроезофагеальна рефлюксна хвороба: шляхи вдосконалення діагностики та лікування / М. А. Бичков // Здоров'я України. - 2016. - № 3. - С. 63.

3. Бичков М. А. Стиль життя та поширеність симптомів гастроезофагеальної рефлюксної хвороби у студентів / М. А. Бичков, Г. М. Магльована // Acta medica leopoliensia. - 2015. - № 4. - C. 38-43.

4. Ендоскопічна діагностика гастроезофагеальної рефлюксної хвороби / О. О. Крилова, Т. В. Майкова, В. М. Кутняк, С. Ю. Єршова // Сучасна гастроентерологія. - 2016. - № 6 (92). - С. 109-118.

5. Чернобровий В. М. Гастроезофагеальна рефлюксна хвороба: функціональна діагностика, вибір
При повторному зверненні впродовж 20112015 років у 9 (0,9 \%) хворих залишалися ендоскопічні ознаки ГЕРХ.

Результати аналізу 5-річного дослідження свідчать, що ерозивні зміни стравоходу виявлені практично у кожного десятого пацієнта, який проходив ендоскопічне обстеження. Встановлено, що найчастіше езофагіт стадії А зустрічався у хворих до 45 років, а езофагіт стадії В - у пацієнтів віком 46-60 років. У хворих віком понад 60 років домінує ураження стравоходу, характерне для стадії С. Виявлено часте поєднання ерозивних змін слизової оболонки стравоходу з патологією шлунка та дванадцятипалої кишки. Ймовірно, самолікування та пізнє звернення за медичною допомогою призводять до поєднаного ураження верхніх відділів шлунково-кишкового каналу.

Висновки. Поширеність ГЕРХ на території обслуговування Новояворівської РЛ № 1 становить 7,6-23,9\%.

Найхарактернішим проявом ерозивних змін стравоходу є езофагіт стадії А (80,3-94 \%).

Найчастіше ендоскопічно позитивну форму ГЕРХ виявляли у пацієнтів працездатного віку.

Перспективи подальших досліджень полягають у детальнішому вивченні етіології та патогенезу ГЕРХ, розробці методики ранньої діагностики для ефективного скринінгу. Це дозволить проводити якісне і вчасне лікування та запобігати виникненню ускладнень ерозивного езофагіту.

інгібіторів протонної помпи та оцінка ефективності їх кислотосупресивної дії / В. М. Чернобровий, С. Г. Мелащенко, О. О. Ксенчин // Сучасна гастроентерологія. -2015 . - № 3 (83). - С. 50-58.

6. Порушення функціонального стану ендотелію та його роль у патогенезі гастроезофагеальної рефлюксної хвороби в поєднанні з ішемічною хворобою серця / Г. Д. Фадєєнко, В. Ю. Гальчінська, І. Е. Кушнір [та ін.] // Сучасна гастроентерологія. - 2016. - № 5 (91). - С. 9-14.

7. Фролова-Романюк Е. Ю. Особливості клінічної картини та лікування гастроезофагеальної рефлюксної хвороби при поєднанні її з цукровим діабетом 2 типу / Е. Ю. Фролова-Романюк // Сучасна гастроентерологія. - 2011. - № 1. - C. 111-115.

8. Blondeau K. Treatment of gastro/esophageal reflux disease: the new kids to block / K. Blondeau // Neurogastroenterol. Motil. - 2010. - Vol. 22.- P. 836-840.

\section{REFERENCES}

1. Babak, O.Ya. (2014). Gastroezofagealnaya reflyuksnaya bolezn. Ot teorii k praktike [Gastroesophageal reflux disease.

From theory to practice]. Suchasna gastroenterolohiia Modern Gastroenterology, 4, 38-44 [in Russian]. 
Огляди літератури, оригінальні дослідження, погляд на проблему

2. Bychkov, M.A. (2016). Gastroezofahelna refliuksna khvoroba: shliakhy vdoskonalennia diahnostyky ta likuvannia [Gastroesophageal reflux disease, ways to improve the diagnosis and treatment]. Zdorovia Ukrainy Health of Ukraine, 3, 63 [in Ukrainian].

3. Bychkov, M.A., Mahlovana, H.M. (2015). Styl zhyttia ta poshyrenist symptomiv hastroezofahelnoi refliuksnoi khvoroby u studentiv [Lifestyle and prevalence of symptoms of gastroesophageal reflux disease in students]. Acta Medica Leopoliensia, 4, 38-43 [in Ukrainian].

4. Krylov, O.O., Maikova, T.V., Kutniak, V.M., \& Ershov, S.Yu. (2016). Endoskopichna diahnostyka hastroezofahelnoi refliuksnoi khvoroby [Endoscopic diagnosis of gastroesophageal reflux disease]. Suchasna gastroyenterologiya - Modern Gastroenterology, 6 (92), 109-118 [in Ukrainian].

5. Chernobrovyi, V.M., Melashchenko, S.H., Ksenchyn, A.A. (2015). Hastroezofahelna refliuksna khvoroba: funktsionalna diahnostyka, vybir inhibitoriv protonnoi pompy ta otsinka efektyvnosti yikh kyslotosupresyvnoi dii [Gastroesophageal reflux disease, functional diagnostics, the choice of proton pump inhibitors and the effect of their actions kyslotosupresyvnoyi]. Suchasna gastroenterolohiya - Modern Gastroenterology, 3 (83), $50-58$ [in Ukrainian].

6. Fadieienko, H.D., Halchinska, V.Yu., Kushnir, I.E. (2016). Porushennia funktsionalnoho stanu endoteliiu ta yoho rol u patohenezi hastroezofahelnoi refliuksnoi khvoroby $v$ poiednanni z ishemichnoiu khvoroboiu sertsia [Violation of the functional state of the endothelium and its role in the pathogenesis of gastroesophageal reflux disease combined with coronary heart disease]. Suchasna gastroyenterologiya Modern Gastroenterology, 5 (91), 9-14 [in Ukrainian].

7. Frolova-Romaniuk, E.Yu., (2011). Osoblyvosti klinichnoi kartyny ta likuvannia hastroezofahelnoi refliuksnoi khvoroby pry poiednanni ii z tsukrovym diabetom 2 typu [Clinical features and treatment of gastroesophageal reflux disease in combination with its type 2 diabetes]. Suchasna gastroyenterolohiya - Modern Gastroenterology, 1, 111-115 [in Ukrainian].

8. Blondeau, K. (2010). Treatment of gastro/ esophageal reflux disease:the new kids to block. Neurogastroenterol. Motil., 22, 836-840.

\title{
РАСПРОСТРАНЕННОСТЬ ГАСТРОЭЗОФАГЕАЛЬНОЙ РЕФЛЮКСНОЙ БОЛЕЗНИ ПО ДАННЫМ ЭНДОСКОПИЧЕСКИХ ИССЛЕДОВАНИЙ
}

\author{
๑М. А. Бычков, М. М. Яхницкая \\ Львовский национальный медицинский университет имени Данила Галицкого
}

PЕЗЮМЕ. Гастроэзофагеальная рефлюксная болезнь (ГЭРБ) остается на сегодня одной из наиболее актуальных проблем гастроэнтерологии. Широкая распространенность данной патологии среди лиц трудоспособного возраста ухудшает социально-экономические условия их жизни и требует дальнейших исследований для ранней диагностики и лечения. Разнообразие клинических проявлений, не до конца выясненные этиопатогенетические звенья обусловливают постоянный интерес к изучению ГЭРБ. К сожалению, достоверные данные о распространенности ГЭРБ в Украине практически отсутствуют.

Цель - исследовать распространенность эндоскопически позитивной формы ГЭРБ среди пациентов Новояворовской районной больницы в течение 2011-2015 годов.

Материалы и методы. Ретроспективно проанализированы журналы регистрации эндоскопических исследований с 2011 по 2015 год. Эндоскопические исследования проводили фиброгастроскопами фирмы Olympus и Pentax. Изменения слизистой оболочки пищевода определяли по Лос-Анджелесской системе классификации (1997). Компьютерную обработку данных проводили с помощью программы Microsoft Excel.

Результаты. За период 2011-2015 гг. выполнено 7571 эндоскопию, у 959 обследованных (12,7 \%) диагностирован эрозивный эзофагит. В 2011 г. выявлен 241 пациент с эрозивными изменениями пищевода: ст. А230 больных, ст. В - 10 человек и ст. D - 1 больной. За 2012 год диагностировано 117 случаев эзофагита: 110 - ст. A, 6 - ст. В, 1 - ст. С. В течение 2013 было установлено 239 случаев эзофагита: 197 - ст. А, 34 - ст. В, 5 - Ст. С и 3 - ст. D. Структура эндоскопически позитивной ГЭРБ в 2014 году была следующей: 94 случая эзофагита ст. А, 20 - ст. В и 3 ст. С. В 2015 году выявлено 245 пациентов с эрозивным эзофагитом, из них 201 - ст. А, 41 - ст. В и 3 человек - ст. С.

Выводы. Распространенность эндоскопически позитивной формы ГЭРБ в 2011-2015 годах на территории обслуживания Новояворовской РБ № 1 составляла в среднем 13,4 \%. Наиболее характерным для эрозивных поражений пищевода был эзофагит ст. А. Зачастую эрозивный эзофагит выявляли среди пациентов трудоспособного возраста.

КЛЮЧЕВЫЕ СЛОВА: гастроэзофагеальная рефлюксная болезнь; эрозивный эзофагит; распространенность. 


\title{
PREVALENCE OF GASTROESOPHAGEAL REFLUX DISEASE ACCORDING TO THE RESULTS OF ENDOSCOPIC EXAMINATIONS
}

\author{
@M. A. Bychkov, M. M. Yakhnytska \\ Danylo Halytskyi Lviv National Medical University
}

SUMMARY. Gastroesophageal reflux disease (GERD) remains nowadays one of the most currently important problems of gastroenterology. The high prevalence rate of this pathology among people of working age affects negatively the social and economical conditions of their life, so more profound research for early recognition and treatment is required. The diversity of clinical manifestations and not entirely cleared up etiological and pathogenetic chains determine unfailing interest in research of GERD. Unfortunately, there are actually no reliable data about the prevalence rate of GERD in Ukraine.

The aim - to study the prevalence rate of endoscopic positive form of GERD among patients of the Novoiavorivsk District Hospital (Lviv Region) during 2011-2015.

Materials and Methods. Retrospective analysis of the registration logs of the endoscopic examinations from 2011 to 2015 was carried out. The endoscopic examinations were conducted with fibergastroscopes Olympus and Pentax. Changes of esophageal mucosa were determined according to the Los Angeles classification system (1997). The computer data processing was carried out with Microsoft Excel.

Results. As of from 2011 to 2015, 7571 endoscopic examinations were carried out, of which in 959 examined patients (12.7\%) erosive esophagitis was recognized. In 2011, there were 241 patients with erosive changes of the esophagus: stage A - 230 patients, stage B - 10 patients, and stage D - 1 patient. In 2012, 117 cases of esophagitis were registered: stage $A-110$ cases, stage $B-6$ cases, stage $C-1$ case. In 2013, 236 cases of esophagitis were recognized: stage A - 197 cases, stage B - 34 cases, stage $C-5$ case, and stage D - 3 cases. The structure of the endoscopic positive GERD in 2014 was as follows: stage A - 94 cases of esophagitis, stage B - 20, stage C - 3. In 2015, there were recognized 245 patients with erosive esophagitis, of which stage A - 201 patients, stage B -41 patients, and stage $C-3$ patients.

Conclusions. The prevalence of the endoscopic positive form of GERD during the period from 2011 to 2015 was on average of $13.4 \%$ within the territory of medical supplies of the Novoiavorivsk District Hospital No. 1. The most distinctive for the erosive damage was esophagitis of stage A. The most frequently, erosive esophagitis was recognized in patients of working age.

KEY WORDS: gastroesophageal reflux disease; erosive esophagitis; prevalence. 